Historia Slavorum Occidentis

2018, nr 4 (19)

ISSN 2084-1213

DOI: $10.15804 /$ hso180404

\author{
EduARD MÜHLE (MÜNSTER)
}

\title{
Inventing Slavic Unity or the Political Use of a Romantic Concept. The Case of Mikhail P. Pogodin and Joachim Lelewel
}

Słowa kluczowe: idea słowiańska, panslawizm, Polska, Rosja, Lelewel, Pogodin, historiografia

Keywords: Slavic idea, Panslavism, Poland, Russia, Lelewel, Pogodin, historiography

\begin{abstract}
Against the background of modern nation-building the article looks at the work of two eminent $19^{\text {th }}$ century historians, the Pole Joachim Lelewel and the Russian Mikhail Pogodin. The text investigates how they tried to shape a modern Slavic Idea by means of historical and political writing.
\end{abstract}

The notion developed in linguistics of a kinship between all Slavs was just as enthusiastically received by Slavic-speaking intellectuals at the turn of the $18^{\text {th }}$ to the $19^{\text {th }}$ century as the Enlightenment idea of the equality of all peoples, the romantic ideal of a humanity with a Slavic influence, and the emancipatory vision of national liberation. Even though the development of national self-awareness among the Slavs did not require this external impetus, the Slavic-speaking elites gladly accepted the external inspiration as confirming their sense of themselves, and based their own political claims upon it ${ }^{1}$. These claims were directed against an ancien régime shaken but

1 H. Sundhaussen, Der Einfluss der Herderschen Ideen auf die Nationsbildung bei den Völkern der Habsburger Monarchie, München 1973; M. Wawrykowa, Johann Gottfried Herder und die polnische Geschichtsphilosophie der ersten Hälfte des 19. Jahrhunderts, Zeitschrift für Slawistik 23 (1978), pp. 835-843; P. Drews, Herder und die Slaven. Materialien zur Wirkungsgeschichte bis zur Mitte des 19. Jahrhunderts, München 1990. 
by no means destroyed by the French Revolution and the Napoleonic wars, a régime that subjected the Slav peoples to varying intensities of foreign rule. Only the East Slav Russians possessed in the tsarist empire state autonomy, whose monarchicalautocratic form, however, tended to reinforce restorative oppression rather than promote Slavic hopes of emancipation. Nevertheless, the idea of a Slavic community constituted by a common language, early history, and culture, the idea of one Slavic nation as represented since the 1780 s by, for example, the Bohemian Enlightenment figure Josef Dobrovský (1753-1829), was initially not intended or exploited politically $^{2}$. The early representatives of pan-Slavic ideas were concerned with raising the profile of a linguistic and cultural commonality to promote "Slavic reciprocity”. Only in this sense did the Slovakian Ján Kollár (1793-1852) call on the „scatter[ed] Slavs” in 1824 to "unite into a whole and no longer be mere fragments" ${ }^{\text {. This wholeness }}$ was to be realized not by means of political amalgamation, but through cultural work, material support for schools, professorships for Slavic languages, bookshops, magazines, congresses, journeys, through fostering appropriate contacts and correspondence among intellectuals ${ }^{4}$.

It was only in the further course of the $19^{\text {th }}$ century that the concept of Slavic reciprocity took on an increasingly political hue, and the idea of a special Slavic community was developed into an instrument of concrete national-political demands

2 J. Dobrovský, Institutiones linguae slawicae dialecri veteris, Wien 1822; idem: Slavín. Botschaft aus Böhmen an alle slawischen Völker oder Beiträge zur Kenntnis der slavischen Literatur nach allen Mundarten, Prag 1806.

3 J. Kollár, Slávy dcera we třech zpèwych, Buda 1824; quoted according to Slávy dcera. Lyricko-epická báseň v pètí zpèvích. Z přídavkem básní drobnějšich, Praha 1868, p. 183: Slávové, vy národ zlomkovitý! / Sily sjednocené dẻlaji.

4 M. Weingart, Rozpravy o Slovanské vzájemnosti, ed. J. Kollár, Praha 1929, p. 39; first published as O literárnej vzájemnosti mezy kmeny a nářeč́mi slavskými, [in:] Hronka 1 (1836), pp. 39-53; enlarged German edition („Über die literarische Wechselseitigkeit zwischen den verschiedenen Stämmen und Mundarten der slawischen Nation”) Pest 1837; an English translation gives Ján Kollár, Reciprocity Between the Various Tribes and Dialects of the Slavic Nation, ed. A. Maxwell, Bloomington 2008; on Kollár and his concept of Slavic reciprcity cf. A. Maxwell, Ján Kollár's Literary Nationalism, ibidem pp. 1-67; V. Matula, Kollárovská a śtúrovska koncepcia Slovanstva a slovanskej vzájomnosti, [in:] Štúdie $z$ dejín svetovej slavistiky do polovice 19. storočia, J. Hrozienčik, Bratislava 1978, pp. 259-288; E. Várossová, Herders Einfluß in der Slowakei. Kollars Idee der slawischen Wechselseitigkeit als Beförderung der Humanität zwischen den Nationen, [in:] Verdrängter Humanismus - verzögerte Aufklärung, Bd. 3: Bildung und Einbildung. Vom verfehlten Bürgerlichen zum Liberalismus. Philosophie in Österreich (1820-1880), M. Benedikt et al., Klausen-Leopoldsdorf 1995, pp. 329-341; Ján Kollár a slovanská vzájomnost'. Genéza nacionalizmu v střédnej Európe, ed. T. Ivantyšynová Bratislava 2006. 
and constitutional plans. However, the overarching Slavic idea fell from the very outset into a striking contradiction with its diverse sub-regional varieties. Ultimately, the increasing numbers of scholarly works on Slavic history, literature, and language not only highlighted the kinship and commonality of all Slavs, but also emphasized at the same time the individual characteristics of the individual Slavic "tribes"s. In doing so, they inevitably inspired the national awakening of the individual peoples, and tended to promote more their particular egoisms than the idea of a general Slavic solidarity. When the political crises of the 1840 s to 1860 s repeatedly called for the Slavic leaders to come together to consider the future, then national $\left(\mathrm{Czech}^{6}\right.$, Slova$\left.\operatorname{kian}^{7}\right)$, unitarian (Greater Serbian ${ }^{8}$, Greater Croatian $\left.{ }^{9}\right)$, and federal („Illyrian” ${ }^{\prime 10}$ and "Austro-Slav"11) interpretations of the Slavic idea stood somewhat in each other's way. A common denominator between the divergent political interests and different

5 On the development of Slavic Studies during the first half of the 19th century Štúdie z dejin svetovej slavistiky do polovice 19. storočia, J. Hrozienčik, Bratislava 1978; L'idea dell'unità e della reciprocità slava e il suo ruolo nello sviluppo della slavistica, S. Bonazza/G. Brogi Bercoff, Roma 1994; W. Zeil, Slawistik in Deutschland. Forschung und Informationen über die Sprachen, Literaturen und Volkskulturen slawischer Völker bis 1945, Köln et al. 1994, pp. 105-195.

6 V. Št'astný, Die slawische Idee bei den Tschechen bis zum österreichisch-ungarischen Ausgleich, [in:] Die slavische Idee, ed. A. Moritsch, Bratislava 1992, pp. 49-54; Z.V. David, Realism, Tolerance and Liberalism in the Czech National Awakening: Legacies of the Bohemian Reformation, Washington 2010, esp. pp. 106-129.

7 E. Bosák, Slavism and the Slovak Intelligentsia. An Instrument of Self-Defense in the Slovak National Movement in the Nineteenth Century, South-East European Monitor 4 (1997), pp. 25-40; L. Haraksim, Slovak Slavism and Panslavism, [in:] Slovakia in History, ed. M. Teich, New York 2011, pp. 101-119 .

8 P.N. Hehn, The Origins of Modern Pan-Serbism - The 1844 Načertanije of Ilja Garašanin. An Analysis and Translation, East European Quarterly 9 (1975), pp. 153-171; H. Sundhaussen, Geschichte Serbiens. 19.-21. Jahrhundert, Wien et al. 2007, pp. 88-97.

9 W.D. Behschnitt, Nationalismus bei Serben und Kroaten 1830-1914. Analyse und Typologie der nationalen Ideologie, München 1980, esp. pp. 172-186, 231-232; A. Rahten, Savezništva i diobe. Razvoj slovensko-hrvatskih političkih odnosa u Habsburškoj Monarhiji 1848.-1918., Zagreb 2008, esp. pp. 61-72.

10 Illirizm, ed. A.I. Leščilovskaja, V.I. Frejdzon, Moskva 1968; A.P. Maissen, Wie ein Blitz schlägt es aus meinem Mund. Der Illyrismus: Die Hauptschriften der kroatischen Nationalbewegung 1830-1844, Bern 1998; K. Novak, Višejezičnost i kolektivni identiteti ilirica. Jezične biografije Dragojle Jarnević, Ljudevita Gaja i Ivana Kukuljevića Sakscinskoga, Zagreb 2012.

11 Der Austroslawismus. Ein verfrühtes Konzept zur politischen Neugestaltung Mitteleuropas, ed. A. Moritsch Wien et al. 1996; Der Prager Slavenkongress 1848, ed. A. Moritsch, Wien et al. 2000; The Prague Slav Congress 1848. Slavic Identities, ed. H. Haselsteiner, New York 2000; H.H. Hahn, Der Austroslawismus. Vom kulturellen Identitätsdiskurs zum politischen Konzept, [in:] Habsburg und die Slavia, ed. Gun-Brit Kohler, Frankfurt/M. 2008, pp. 49-75. 
socio-cultural backgrounds of the Slavs living under Austrian, Prussian, Russian, and Ottoman rule could not really be found.

A common course of political action in the spirit of general Slavic solidarity and commonality was hindered not least by the very separate attitude that the two numerically largest historical Slavic nations - the Poles and the Russians - took regarding the Slavic idea. Polish thinkers understood the pan-Slavic concept primarily as a means of fighting to regain Polish statehood and East Central European pre-eminence. Russian intellectuals, on the other hand, exploited the Slavic idea primarily to legitimize tsarist-imperial claims of domination. Interestingly, the Poles initially backed Russia with their pan-Slavic efforts, since it was under Russia's dominion that in 1815 large parts of their territory had been brought together in a recovered though curtailed "kingdom of Poland”. Thinkers and scholars such as Stanisław Staszic (1755-1826), Wawrzyniec Surowiecki (1769-1827), or Zorian Dołęga Chodakowski (1784-1825) harboured the hope that Poles and Russians, as the two most important Slav peoples, could jointly bring about a new epoch for humanity, one shaped by the Slavs ${ }^{12}$. But such Russophile visions soon disappeared under the yoke of tsarist oppression, and were replaced at the latest after the failed November insurrection of $1830-31$ by a new variant of the Slavic idea that was explicitly directed against Russian foreign dominance - the idea of „Polish messianism". Its most important representative among the Polish romantics was the poet Adam Mickiewicz (1798-1855), who taught in Paris at the beginning of the 1840s. He considered Catholic Poland to be the most noble Slavic and at the same most Christian nation, and therefore ascribed to it a special mission, not only among the Slavs, but also among all European peoples. He virtually turned the Polish nation into a suffering messiah of the peoples, whose victims the Slavs and Europe should release from the antichrist Russia (now characterized not as Slavic, but as Asiandespotic $)^{13}$. Other Polish romantics argued less messianically, but they nevertheless

12 V.A. Francev, Pol'skoe slavjanovedenie konca XVIII i pervoj četverti XIX st., Praga Českaja 1906; Z. Klarnerówna, Stowianofilstwo w literaturze polskiej lat 1800 do 1848, Warszawa 1926, pp. 24-69; A. Wierzbicki, Mit czy rzeczywistość? „Stowiańszczyzna” w myśli historycznej polskiego romantyzmu, [in:] Stowianie, stowiańszczyzna - pojęcie i rzeczywistość dawniej i dziś, ed. K. Handke, Warszawa 2002, pp. 59-76; L. Moroz-Grzelak, Bracia Stowianie. Wizje wspólnoty a rzeczywistość, Warszawa 2011, pp. 36-50.

13 M. Cieśla-Korytowska, Mickiewicz et les Slaves: que peuvent-ils offrir à l'Occident?, [in:] The Slavs in the Eyes of the Occident, the Occident in the Eyes of the Slavs, ed. eadem, Cracow-Boulder 1992, pp. 83-93; A. Walicki, Mesjanizm Adama Mickiewicza w perspektywie porównawczej, Warszawa 2006, pp. 125-177; M. Rudaś-Grodzka, Versklavtes Slawentum. Messianismus und Masochismus bei Mickiewicz, Osteuropa 59 (2009), 12, pp. 193-211; L. Moroz-Grzelak, Bracia (as in footnte 12), pp. 54-66; 
glorified the Slavs as a specific community, and foresaw for this community a great future under Polish leadership. They, too, were therefore striving in essence for nothing less than a restoration of the Polish Noble Republic.

Among the latter was Joachim Lelewel (1786-1861), a historian and politician who gained particular importance in the political and cultural life of divided Poland $^{14}$. The son of a Warsaw official and nobleman of German descent, Lelewel had received from the newly founded University of Wilno/Vilnius (1803) a wideranging historical and philological education strongly influenced by the ideas of the Enlightenment and the new current of Romanticism ${ }^{15}$. After finishing his studies without formal qualification in $1808^{16}$, he worked briefly as a teacher in the Polish Lyceum of Krzemieniec as well as in the Warsaw Ministry of the Interior. Dissatisfied with these activities, he soon withdrew to his father's estate and devoted himself entirely to scholarship. He then returned to the University of Vilnius - initially, in 1815 , with a temporary teaching contract, and then in 1821 as a full professor in general history. In the meantime, he worked from 1818 to 1821 as a librarian in Warsaw, where he played a major role in the construction of the Polish national library. In Vilnius, he developed a modern theory and methodology for the historical sciences, thereby placing Polish historical research on a serious academic basis for the first time and building for himself a reputation as a pioneer of contemporary European historical thought ${ }^{17}$. As a university lecturer, he strove to teach his

Z. Kaźmierczyk, Stowiańska psychomachia Mickiewicza, Gdańsk 2012; M. Ruszczyńska, Stowianie i stowianofile. O stowiańskich dyskursach w literaturze polskiego romantyzmu, Kraków 2015, pp. 54-66.

14 For the most important biographical studies cf. A. Śliwiński, Joachim Lelewel. Zarys biograficzny. Lata 1786-1831, Warszawa 1918; I. Chrzanowski, Joachim Lelewel. Cztowiek i pisarz, Warszawa 1946; M.H. Serejski, Joachim Lelewel 1786-1861. Sa vie et son oeuvre, Warszawa 1961; S. Kieniewicz, Joachim Lelewel, Warszawa 1990; J. D. Stanley, Joachim Lelewel (1786-1861), [in:] Nation and History. Polish Historians from the Enlightenment to the Second World War, ed. P. Brock et al., Toronto 2006, pp. 52-84.

15 Cf. the autobiographical notes J. Lelewel, Przygody w poszukiwaniach $i$ badaniu rzeczy narodowych polskich, [in:] idem: Materiaty autobiograficzne, Warszawa 1957 [Joachim Lelewel, Dzieła, Bd. 1, ed. H. Więckowska], pp. 36-152, here pp. 38-43.

16 Only in June 1820 the University of Cracow awarded him acknowledging his scholarly work published to that moment a $\mathrm{PhD}$.

17 J. Lelewel, Historyka, tudzież o tatwym i pożytecznym nauczaniu historii, Wilno 1815; idem, O potrzebie gruntownej znajomości historii i na czym ta gruntowność zależy, Wilno 1817; idem, Nauki dające poznawać żródta historyczne, Wilno 1822; idem, O historii, jej rozgatęzieniu i naukach zwiazek z niq mających, Warszawa 1826; see also N. Assorodobraj, Ksztattowanie się zatożeń teoretycznych historiografii Joachima Lelewela (okres przedpowstaniowy), [in:] Z dziejów polskiej myśli filozoficznej i spo- 
students through imparting both a knowledge of history and a deep love for the fatherland and own nation, but also an insight into the necessity of fundamental social change. This earned him high recognition among his young listeners, but made him politically suspect in the eyes of the tsarist authorities. When, in the spring of 1824, the latter cracked down on the secret student societies in Vilnius, the socalled Philomaths and Filarets, and exiled some of their members, including Adam Mickiewicz, to Russia, Lelewel also lost his professorship ${ }^{18}$. Banished from Vilnius, he retreated to Warsaw to devote himself for a while to an intense period of archaeological and numismatic studies. But, in 1828, he again left his study room and took on an electoral mandate in the Sejm, quickly gaining influence as a progressive liberal on those political and academic circles from which the leaders of the November uprising of 1830 would soon come. He considered the timing and preparation of the uprising as unfortunate, but nevertheless served as an adviser to the insurgents. In January 1831, he temporarily assumed responsibility in the newly-formed Polish national government, where he worked not only for national liberation, but also for the emancipation of the peasants. Faced with the resistance of the monarchists, his revolutionary projects failed, however, even before the insurrection was defeated ultimately by the tsarist troops in the late summer of $1831^{19}$. But, even in exile in Paris, Lelewel remained true to his progressive views. He joined the leadership of the „Polish National Committee”, in which the democratic camp of emigrants organized themselves, and, in the hope of a general European revolution, campaigned diligently for the Polish cause. When the French government (apparently at the instigation of the Russian authorities) ordered the expulsion of members of the „National Committee” in 1833, Lelewel went to Brussels, where he spent the rest of his life. In Brussels, too, he remained torn between scholarship and the political

tecznej, vol. III: Wiek XIX, ed. B. Baczko, N. Assorodobraj, Warszawa 1957, pp. 112-194; M.H. Serejkki, Koncepcja historii powszechnej Joachima Lelewela, Warszawa 1958; idem, Joachim Lelewel et la science historique de son temps, Wroclaw 1963; for an innovative comparison of the works written in 1815-1833 by Joachim Lelewel and Adam Mickiewicz D. Zawadzka, Lelewel i Mickiewicz. Paralela, Białystok 2013.

18 On Lelewel's political activities in Vilnius K. Żukowska, Wychowankowie Uniwersytetu Wileńskiego wświetle korespondencji, wspomnień, dokumentów. Joachim Lelewel i Szymon Żukowski, Warszawa 2008; H.M. Słoczyński, Światto w dziejarskiej ciemnicy. Koncepcja dziejów i interpretacja przesztości Polski Joachima Lelewela, Kraków 2010, pp. 69-74, 99-101, 134-157.

19 On Lelewel's activities in Warsaw before and during the November uprising S. Wyspiański, Warszawianka. Lelewel, noc listopadowa, Wroclaw et al. 1967; A. Kowalska, Mochnacki i Lelewel wspóttwórcy umystowego Warszawy i kraju. 1825-1830, Warszawa 1971. 
stage, but withdrew more and more from active politics after the failure of the 1848 revolutions. In the end, he devoted himself entirely to his scholarly work ${ }^{20}$.

This work focused on universal history, the history of the antiquity, but, above all, on Polish history. It was the search for the historical individuality of the Polish nation, the struggle for its political autonomy and social continuity, as well as the republican ideal of a society based on freedom and equality amongst its citizens, that shaped not only Lelewel's political activity, but also his historiographical work ${ }^{21}$. Neither the Slavic idea nor pan-Slavic history had a particularly prominent or independent position in this work ${ }^{22}$. Nevertheless, central aspects of this idea, such as the notion of a common early history and the emphasis on common Slavic characteristics, as well as the myth of a unique Slavic form of primal democracy, were always present ${ }^{23}$. Although Lelewel was never concerned with a history of the Slavs as such, and he hardly dealt with the history of other Slav peoples in more detail, these aspects were important components of his historiographical constructions. They were central building blocks in his interpretation of the history of the Polish nation and its particular historical calling.

Lelewel had already dealt with early Slavic history in his early work in universal history when he wrote on the antiquity and the origins of European peoples ${ }^{24}$.

20 On Lelewel in exile B. Cygler, Działalność polityczno-społeczna Joachima Lelewela na emigracji w latach 1831-1861, Gdańsk 1969; Joachim Lelewel à Bruxelles de 1833 á 1861. Actes du colloque organisé les 17 et 18 avril 1986 par le Centre International Lelewel d'Études et d'Informations Historiques, ed. T. Wysokinska, Bruxelles 1987.

21 Cf. J.S. Skurnowicz, Romantic Nationalism and Liberalism: Joachim Lelewel and the Polish National Idea, Boulder-New York 1981; A. Wierzbicki, Historiografia polska doby romantyzmu, Wrocław 1999, pp. 307-336.

22 Cf. T. Zawadzki, Joachim Lelewel jako badacz świata starożytnego. Próba charakterystyki, Przegląd Historyczny 43 (1952), pp. 177-194; K. Tymieniecki, Joachim Lelewel - dziejopis dawnych Stowian, Kultura i społeczeństwo 2 (1958), 2, pp. 6-21, esp. p. 6.

23 J. Kurczak, Historiozofia nadziei. Romantyczne słowianofilstwo polskie, Łódź 2000, pp. 64-75, 88-92, 129-139; H.M. Słoczyński, Światto (as in footnote 18), esp. pp. 301-360; Z. Kaźmierczyk, Stowiańska psychomachia (as in footnote 13), pp. 28-45; M. Michalski, Dawni Stowianie w tradycji polskiej pierwszej połowy XIX wieku. W poszukiwaniu tożsamości wspótnotowej, Poznań 2013, pp. 95-96, 120-123, 167-173, 183-184.

24 J. Lelewel, Rzut oka na dzieje narodów przed czasokresem chrześcijańskim z roztrzą́nięciem ich początków i pochodzenia, unpublished 1806, as manuscript available in Biblioteka Jagiellońska Kraków, ręk. 3503; [idem], Edda, czyli księga religii dawnych Skandynawii mieszkańców, Wilno 1807; idem, Opis pótnocnej Europy w Księdze XXII, 8 Ammiana Marcelina wykład przeciw Naruszewiczowi, Wilno 1808; these an other studies on early Slavic history brought together in a revised version in idem: 
In doing so, he drew mainly on the reports of ancient written sources, which are sometimes still today related to the Slavs, but also made use of archaeological, onomatological and numismatic sources, as well as insights from historical geography. Lelewel derived a common Slavic origin and unity already from the very name of the Slavs, since, for him, it is used in the same way by all Slavs. A further startingpoint for his reflections were the large number and wide geographical spread of the Slavs (also derived from linguistic kinship). Both led Lelewel to the opinion that the Slavs must be a long-established people in Eastern Europe, and could not have descended from the Scythians or Sarmatians, and nor have emigrated from India, as had generally been assumed until then ${ }^{25}$. But, since they appeared as „Slavs” only late and all of a sudden, Lelewel sought to strengthen his thesis that the Slavs were a long-established people by identifying them both with the Thracians described by Herodotus and the later Dacians ${ }^{26}$. In doing so, he relativized his theory of autochthonism by assuming a spread of the Thracians/Dacians/Slavs from the south to the north, therefore identifying the ancestors of the Poles as coming from „beyond the Carpathians". To that end, he drew on Roman sources on the Dacia campaigns of Emperor Trajan (53-117), such as the iconography of the Trajan column, and on the Rus' Nestor chronicle of the early $12^{\text {th }}$ century, which, as we know, was the first to assume a southern origin of the Slavs. He further complicated this vague and inconsistent theory of origin by assuming a fusion between the Dacians who had wandered northward and the ancient Venetians that they met there, whom he also saw as Slavic. As proof he forwarded among other things identical river names from ancient Moesia and Dacia, and from the Vistula and Dniester area.

In the light of Lelewel's personal experience of emigration, this speculative construction gained a contemporary historico-political dimension in two respects. First, by emphasizing the autochthonous character of the Slavs, and thus also the longevity of the Poles, he could contradict the idea widespread at the time that Polish early-medieval state-building was a consequence of external conquest. Lelewel

Narody na ziemiach stowiańskich przed powstaniem Polski, Poznań 1853 (quoted after idem: Dzieła, vol. V, ed. K. Tymieniecki, Warszawa 1972). H.M. Słoczyński, Światto (as in footnote 18), p. 295 sees this work as the specific attempt to connect the world of ideals and the mythic origins with the ideals realized in the course of Polish history.

25 J. Lelewel, Edda (as in footnote 24) still derived the Slavs form the Sarmatians; but he soon gave up this traditional interpretion. The following summary of Lelewel's interpretaion of Slavic ethnogeneses after J. Lelewel, Narody na ziemiach stowiańskich (as in footnte 24), chapter VI and VII. 26 With this Lelewel took up J.Ch. Gatterer, Abhandlung über die Frage. Ob die Russen, Polen und übrigen Slavischen Völker von den Geten oder Daciern abstammen, Bremen 1805. 
strongly opposed this argument, since it led to the contemporary notion that the Slavs or Poles were incapable of independent political organization, and he argued instead that the formation of Slavic early-medieval dominions, and thus the formation of Polish statehood, was the result of a long internal structural process. In this way, a certain historical emphasis could be given to the current political demands for the restoration of Polish independent statehood. Second, the idealization of the Dacians/Slavs driven north by Roman foreign rule could promote the heroization of the "Great Emigration”. Just as the ancient Dacians/Slavs had once fled from the Romans as a well-situated people with their entire possessions, before returning gradually to their homeland as soon as the immediate danger of war had passed, so fared the Polish emigrants of 1831, too. Just as the Dacians/Slavs forced north of the Carpathians by Roman oppression had, „inspired by one thought, guided by one feeling", lived peacefully and quietly among themselves according to their character, developed a special sense of honour and a special hospitality, and strengthened their national singularity (narodowość), so the Poles of the 1830s to 1850s could hope for a similar strengthening of their mental state and a brighter national future.

The emphasis on a special character of the Slavs formed the second Slavic motif in Lelewel's historiography. Like some researchers to this day (and before that, in a particularly prominent way, Johann Gottfried Herder), Lelewel uncritically derived the individual elements of this character - the pronounced peacefulness and mildness, the cordial hospitality, the love for settled agriculture, their own primal forms of community and beliefs - from the early Byzantine descriptions of Jordanes, Procopios, Theophylaktos Simokates, and the Strategikon of Maurice ${ }^{27}$. This recourse to the allegedly exclusively positive character traits and high moral values of the old Slavs also served the spiritual strengthening of an independent Polish nation. With this image of the Slavs, the Polish fighters for liberation were to be presented with an exemplary model, a perfect form of their state in the future. The special character of the Slavs could also be drawn on as additional proof of the particular individuality and historical role of the Poles.

One attribute of the Slav character was particularly foregrounded, and indeed raised to an independent motif in Lelewel's historiography: the special sense of Slavic community. Lelewel derived from it not only a special Slavic solidarity constituting Slavic unity in the first place, but also a genuinely Slavic societal and con-

27 Lelewel's scattered studies on the religious beliefs and practices of the old Slavs, whose original monotheism only under the influence of foreign peoples developed into polytheism, put together in J. Lelewel, Cześć bałwochwalcza Stawian i Polski, Poznań 1855. 
stitutional form. On the basis of vague testimonies from early-medieval sources, but especially by means of historiosophical extrapolations from Polish history, he created the image of an original Slavic communal democracy (gminowtadztwo) in which the ideals of the French Revolution, the vision of a free republic of nobles, and the romantic idea of the nation, flowed into one another ${ }^{28}$. For Lelewel, „the high concept of brotherhood" prevailed in this Slavic primal democracy, a concept that made all Slavs equal and free members of one people/tribe. While Lelewel acknowledged that this pre-Christian primal democracy had already created certain inequalities, he argued that these inequalities were purely at the level of property (some tribe members had from a certain moment in time owned more land than others), and that, in terms of self-administration and public life, all tribe members had the same rights ${ }^{29}$. For Lelewel, it was only with the adoption of Christianity, the assumption of Western forms of civilization, and the establishment of monarchical feudal dominions, that real social inequality emerged, with the section of society that had previously been better off only in terms of property being transformed into an aristocratic layer, and a political dominion over the rest of the population developing ${ }^{30}$. The Polish nation, however, had been able to preserve certain rem-

28 The trem gminowtadztwo was used already by W. Surowiecki, Śledzenie poczatków narodów stowiańskich, Warszawa 1824; on Lelewel's concept of gminowtadztwo in detail F. Bronowski, Idea gminowtadztwa we wczesnej twórczości Joachima Lelewela (ze studiów nad dwoma rękopisami z 1806 r.), Zeszyty Naukowe Uniwersytetu Łódzkiego. Nauki Humanistyczno-Społeczne 8 (1958), pp. 51-66; idem, Idea gminowtadztwa w polskiej historiografii (Geneza i formowanie się syntezy republikańskiej J. Lelewela), Łódź 1969, pp. 92-143 und H.M. Słoczyński, Światto (as in footnote 18), pp. 181-294; see also P. Boroń, Gminowładztwo i stowiańska sielanka wedlug stowianofilów. Obraz wieców plemiennych w historiografi wieku XIX, Historie-Historica. Sbornik praci filozofické fakulty Ostravské Univerzity 8 (2000), pp. 111-128; H. Beresenevičiutè-Nosálová, Joachim Lelewel a František Palacký: 'slovanství v historickém a politickém diskursu, [in:] 'Slavme slavně slávu Slávóv slavných. Slovanství a česká kultura 19. století. Sbornik přispěvků z 25. ročníku sympozia k problematice 19. století, Plzeň, 24. 6. února 2005, ed. Zdeněk Hojda et al., Praha 2006, pp. 110-121.

29 This concept, which in essence was only developed during emigration, in detail explained in J. Lelewel, Stracone obywatelstwo stanu kmiecego, [in:] Polska wieków średnich czyli w dziejach narodowych Polskich postrzeżenia, vol. 4, Poznań 1851, pp. 5-33; idem, Historyczny rozbiór prawodawstwa polskiego do czasów jagiellońskich, [in:] Polska wieków średnich, vol. 3, Poznań 1859, pp. 1-113; idem, Histoire de Pologne: considerations sur l'état politique de l'ancienne Pologne et l'histoire de son peuple, Paris 1844; idem, Betrachtungen über den politischen Zustand des ehemaligen Polens und über die Geschichte seines Volkes, Leipzig 1845 [Geschichte Polens, Leipzig ${ }^{2}$ 1847]; idem, Uwagi nad dziejami Polski i ludu jej, [in:] Polska dzieje i rzeczy jej, Bd. 3, Poznań 1855, pp. 29-469, esp. pp. 31-47, 74-99, $173-174,217-218,275-279$.

30 J. Lelewel, Uwagi nad dziejami Polski (as in footnote 29), pp. 49-74. 
nants of the Slavic democratic idea during its medieval and early-modern history, since, according to Lelewel, parts of these traditions had been preserved in the form of Polish aristocratic democracy (gminowtadztwo szlacheckie), even though in this form equality was still valid only for the nobility. On the other hand, the principles of Slavic primal democracy had completely disappeared among the East Slavs as a result of the despotic periods of rule by Scandinavians and Tartars.

With this historiographical construction, Lelewel was claiming for Slavic and Polish history an independent path of historical development, which differed from that of Western Europe and of Russia. At the same time, he ascribed to the Polish nation, as practically the only Slavic nation to have retained at least remnants of the Old-Slavic constitutional conditions, a special liberation mission which would restore the once ideal republican-democratic situation. With the prospect of a return to the glorified Old-Slavic constitutional conditions, Lelewel was offering his Polish compatriots above all a vision of freedom and a future, which also promised to integrate the great mass of peasants and the lower and middle nobility into a free and sovereign Polish nation. But Lelewel by no means addressed his motivating image of the past to the Poles alone, but turned potentially to all „Slav brothers”. He therefore told them in a "call to the Slavs" that he made in March 1844 that "the Poles belong just as much to the tribe of Slavs as you others. The same blood flows in them as in your veins, the same elements gave them origin and existence; together with you all, they live and kindle, in misfortune and hope, nationality and brotherhood. [...] Uniform are the feelings and reciprocal brotherly commonality in confidence in the cause. [...] Chest and heart fulfill the same wish, they strive towards the one aim of freedom, and they reach out their brotherly hand to each other" ${ }^{31}$. This hand Lelewel did not wish to keep from the „Russian brothers”, even though he denied in essence a Slavic character to the despotism of the tsarist empire ${ }^{32}$. Even after the failed November uprising, he continued to hope also for the solidarity and will to freedom of the East Slavs. In an appeal of the Polish National Committee, he reminded them in 1832 with the "voice of the oppressed and of Slavdom groaning in bondage" of the "great idea of a federation of the Slav peoples", as the Decabrists had already proclaimed this idea in their time. For Lelewel, this idea must now actually be realized through a common Slavic renaissance. For that, according to Lelewel, „the

31 Komitet Narodowy Polski do Stowian [25. 3. 1844], [in:] Joachim Lelewel, Wybór pism politycznych, ed. M.H. Serejski, Warszawa 1954, pp. 235-236.

32 Cf. for example J. Lelewel, Dzieje Litwy i Rusi aż do unii z Polska w Lublinie 1569 zawartej, [in:] idem, Dzieła, vol. 10, ed. J. Ochmański, Warszawa 1969, p. 125. 
Slav is willing to give the Slav his brotherly hand, and the Slav will gladly prop the Slav up to achieve freedom”33. But this hope was immediately mixed with a „painful, embarrassing distrust", which made the entire Polish emigrant community oppose the Russian variant of the Slavic idea forming at that time. Thus, Lelewel gave forceful warning not only to the Poles, but also to all "Slav brothers”, of a Russian panSlavism, as it had been propagated for some time by „learned messengers” of the tsar. "They recommend to you the unity of Slavdom through the tsar, they ask you to call on his assistance; [...] he can as 'liberator' give you his hand; he is able and willing, they tell you, to make immeasurable sacrifices for the great tribe, whose chief and deputy he calls himself; he understands your striving for brotherly accord, and he is determined, as your protector, to organize your unity in a Slavic tsardom, under the rule of a paternal autocracy”. Unfortunately, all too many Slavs had allowed themselves to „be blinded” by such promises, and were thereby in danger of „distracting the spirit of their people from the right track of supporting the work of their national empowerment". The tsar's representatives praised Slavdom and its unity, as Lelewel further warned, only to "make it a part of their tsardom, only to instill the principle of despotism on this tribe of people”, while actually "the whole nature of Slavism” goes against this principle. Therefore the „worthy Slavic brothers” could not count on the participation of the Poles in pan-Slavic movements for as long as such activities amounted "even remotely [to] a federation with the tsardom" ${ }^{34}$.

The most prominent Russian „learned messenger” that Lelewel had in mind when issuing such warnings was the historian and journalist Mikhail P. Pogodin (1800-1875). He had been following with interest the scholarly work of his Polish colleague since $1824^{35}$. Although Pogodin strongly condemned the Polish uprising, denied Poland any right to national independence, and felt that the Poles had never

33 Odezwa Komitetu Narodowego do Rosjan [Paris 1832], [in:] Wybór pism politycznych (as in footnote 31), pp. 218-220, here p. 220.

34 J. Lelewel, Der Panslavismus und Polen: ein Sendschreiben an die Redaction der Grenzboten, Die Grenzboten 2 (1843), pp. 681-691, the quotations pp. 281, 283-286; the article offers passages from talks Lelewel had given before in front of Polish compatriots in French and Polish on occasion of commemorating the anniversary of the November uprising; Lelewel himself translated them on invitation of the editorial board of Die Grenzboten.

35 Since the late 1820s Pogodin already was in contact with Lelewel by letters, in which he i.a. explored the possibility of translating works of Lelewel into Russian; cf. B.S. Popkov, Pol'skij učenyj i revoljucioner Ioachim Lelevel'. Russkaja problematika i kontakty, Moskva 1974, pp. 50-52, 61; U. Picht, M.P. Pogodin und die Slavische Frage. Ein Beitrag zur Geschichte des Panslavismus, Stuttgart 1969, pp. 117-118. 
been happier as in the first decades of the $19^{\text {th }}$ century under Russian control, he also maintained his scholarly appreciation of his Polish colleague after $1830 / 31^{36}$. In September 1842, he travelled to Brussels on one of his journeys through Europe especially to have a personal meeting with Lelewel, which the latter himself described as interesting and enjoyable ${ }^{37}$. Lelewel also considered a second personal meeting, in August 1856, as stimulating, while also sarcastically praising his Russian guest as a "propagandist for the notorious Moscow national spirit”; he had joked and exchanged anecdotes with Pogodin, but had also bawled at him ${ }^{38}$.

This national spirit had meanwhile assumed in the circle of a small intellectual elite a quite different hue in the form of "Slavophilism" 39 . Contrary to what the term might suggest, this Slavophile discourse had little to do with the West and South Slavic ideas of Slavic unity and reciprocity. These ideas were rarely taken up in the tsarist empire because they appeared quite undesirable to the autocracy. A collapse of the Hapsburg Empire and a joining of its Slav peoples to Russia were completely out of the question for the strictly legitimate thinker Nicholas I (1796-1855), as his military intervention to suppress the Hungarian revolution showed. „Slavophiles” such as Aleksej S. Chomjakov (1804-1860), Ivan V. Kireevsky (1806-1856), and Konstantin S. Aksakov (1817-1860) also had little interest in the history and culture of other Slav peoples. They were solely concerned in their historico - and religious-philosophical treatment of so-called Russian „Westerners” with the question of the relationship of Russia to Western Europe, and with determining the path that

36 B.S. Popkov, Pol'skij učenyj (as in footnte 35), pp. 161-162.

37 Joachim Lelewel to Jan Lelewel, 30. 10. 1842, [in:] Listy Joachima Lelewela. Oddziat 1: Listy do rodzeństwa pisane, vol. 2, Poznań 1879, pp. 174-177, here 176; Pogodins memory of this encounter reproduced in N.P. Barsukov, Žizn' i trudy M. P. Pogodina. Kniga 7, S.-Peterburg 1893, S. 50-53; cf. also B.S. Popkov, Pol'skij učenyj (as in footnote 34), pp. 196-197.

38 Letter to Teofil Januszewicz, Brussels [13.8.1856], [in:] Listy emigracyjne Joachim Lelewela, vol. 4: 1849-1861 (Nr. 948-1261), ed. H. Więckowska, Kraków 1954, pp. 306-307, here p. 306; for Pogodins memory of this second visit N.P. Barsukov, Žizn' (as in footnote 37). Kniga 14, S.-Peterburg 1901, pp. 609-610.

39 A. Walicki, The Slavophile Controversy. History of a Conservative Utopia in Nineteenth Century Russian Thought, Oxford 1975; N.I. Cimbaev, Slavjanofil'stvo. Iz istorii russkoj obščestvenno-političeskoj mysli XIX veka, Moskva 1986, esp. pp. 33-38; V.A. D'jakov, Slavjanskij vopros v ob̌̌čestvennoj žizni dorevoljuzionnoj Rossii, Moskva 1993; Slavjanofil'stvo i sovremennost'. Sbornik statej, ed. B.F. Egorov et al., Moskva 1994; L. Engelstein, Slavophile Empire. Imperial Russia's Illiberal Path, Ithaca-London 2009; S. Horujy, Slavophiles, Westernizers, and the Birth of Russian Philosophical Humanism, [in:] A History of Russian Philosophy 1830-1930. Faith, Reason, and the Defense of Human Dignity, ed. G.M. Hamburg, R.A. Poole, Cambridge 2010, pp. 27-52. 
Russia should take in the future with regard to its historical mission. Their rigorous rejection of the enlightened-rational way of life of the West, and their glorification of ancient-Russian Orthodox culture, actually turned their Slavophilia into a Russophilia. However, there was also in Russia a pan-Slavic line of thought that was connected to the West Slavic concept of Slavic reciprocity. It developed a genuine interest for the Slavic brothers, and only on this basis did it gradually develop into that particular variant of the Slavic idea known as Russian pan-Slavism. Its most important representative was Pogodin.

The son of a serf emancipated in 1806, Pogodin attended a Moscow high school, studied at Moscow University from 1818, and began to teach first-year students in the fourth year of his studies ${ }^{40}$. After completing his master's dissertation „On the origins of the Rus" in 1824, in which, influenced by August Ludwig Schlözer (1735-1809), he stressed the special role of the Scandinavian Varangians in the founding of the first East Slav state, and by which he aroused much turmoil ${ }^{41}$, he received a lectureship for general history in 1825 . This lectureship was converted into a full professorship in 1833, which two years later Pogodin, with the support of the minister of public education Sergei S. Uvarov (1786-1755), exchanged for the chair of Russian history. Its previous occupant, Michail T. Kačenovskij (1775-1842), had fallen into discredit with the government for criticizing the glorification of Russian early history - which, for example, Nikolai M. Karamzin (1766-1826) had propagated - and was moved within Moscow University to the new professorial chair in the history and literature of Slavic languages ${ }^{42}$. Pogodin did not disappoint the hopes placed on him by the government, and emerged both as a keen critic of his predecessor as well as a vehement advocate of tsarist government policy. He had already in the 1820s in his Historical Aphorisms provided the first historico-theoretical foundations for the Uvarov formula „Autocracy, Orthodoxy, Nationality (narodnost')”43.

40 For recent biographical overviews see K.B. Umbraško, M.P. Pogodin. Čelovek. Istorik. Publicist, Moskva 1999; N.I. Pavlenko, Michail Pogodin, Moskva 2003; A.A. Širinjanc, K.V. Rjasencev, Michail Petrovič Pogodin, [in:] Michail P. Pogodin, Izbrannye trudy, A.A. Širinjanc, K.V. Rjasencev, Moskva 2010, pp. 5-82; cf. also M.B. Petrovich, The Emergence of Russian Pan-Slavism 1856-1870, New York 1956, pp. 26-31, 61-62, 105-107, 117-119; C.H. Porter, Mikhail Petrovich Pogodin and the Development of Russian Nationalism 1800-1856, Nashville 1974.

41 M.P. Pogodin, O proischoždenii Rusi, Moskva 1825.

42 K.-D. Grothusen, Die Historische Rechtsschule Rußlands. Ein Beitrag zur russischen Geistesgeschichte in der zweiten Hälfte des 19. Jahrhunderts, Gießen 1962, pp. 30-32.

43 Since 1823 Pogodin took notes in his diary which developed into historical aphorisms first published in 1827 in Moskovskij Vestnik and in 1834 in the first number of the journal Biblioteka dlja 
Working under the influence of Herder and Schelling, Pogodin put forward in the Aphorisms an organic conception of history that parallelized natural development with the history of humankind, and personified peoples and human individuals in biologistic images. This widened the historian's view, otherwise fixed on Russian national history, to take in a universal historical perspective, in which the Slavs as a whole emerged as a separate, specific organism, as one people. In the Aphorisms, the Slavs therefore already constituted for Pogodin a "separate world” with a special historical mission that could be demarcated from Europe ${ }^{44}$. Even though terminological fluctuations did not fail to arise ${ }^{45}$, Pogodin, with Josef Dobrovský, maintained throughout his life that the Slavs were one people characterized by their original common language, a people that had in the course of history simply been separated into different dialects (narečija) and tribes (plemena) ${ }^{46}$. With Herder and like Lelewel, Pogodin characterized the Slavs as "an agricultural, settled, tranquil, peace-loving people [...] that had waged no wars of conquest, but only of defence", and that as a result "could expand only on the basis of its natural propagation and not violently, like warlike peoples" 47 .

Pogodin's historico-philosophical conception of the Slavs was accompanied from the early 1820 s by a growing interest in concrete Slavic themes and by the desire to strengthen the collection and publication of works "on the subject of the Slavs" within the framework of a future Russian historiography ${ }^{48}$. He himself, together with his friend Stephan P. Ševyrev (1806-1864), undertook to translate into Russian Josef Dobrovskýs Institutiones linguae slavicae dialecti veteris ${ }^{49}$; at the same time, he

čtenija; in bookform the aphorisms appeared in 1836: Istoričeskie aforizmy Michaila Pogodina, Moskva 1836; M.P. Pogodin, Historische Aphorismen, Leipzig 1836; cf. U. Picht, Pogodin (as in footnote 35), pp. 30-31; V.A. D'jakov, Slavjanskij vopros (as in footnote 39), pp. 11-12.

44 M.P. Pogodin, Historische Aphorismen (as in footnote 43), esp. pp. 9 - 10, 34 (here the quotation).

45 Thus Pogodin calls the Slavs also a "group of peoples”, sometimes a „nation” or ,illyric people”; the Russians he sw as a rule as an independent nation of ist own kind; only within a general pan-slavic context he characterized them as a "Slavic tribe”; see also U. Picht, Pogodin (as in footnote 35), pp. 59-60.

46 M.P. P[ogodin], O razdeleniu slovenskago jazyka na narečija, [in:] Moskovskij Vestnik. Čast' četvertaja, Moskva 1827, pp. 177-178.

47 M.P. Pogodin, Lekcja o slavjanach, čitannaja v ètnografičeskom obščestve, Aprelja 4 dnja, 1867 goda, [in:] Michail P. Pogodin, Izbrannye trudy (as in footnote 40), pp. 415-429, here p. 417.

48 Pogodin 1821 in conversation with Aleksej M. Kubarev (1796-1881); the quotation from Pogodin's diary in N.P. Barsukov, Žizn' i trudy M.P. Pogodina, vol. 1, S.-Peterburg 1888, p. 81.

49 The translation was completed in 1826 but published only in 1833: I. Dobrovskij, Grammatika 
engaged with the so-called Slavic apostles Cyril and Methodius, whom he revered throughout his life as the central source of the entire Slavic culture, and whom he once later referred to as the „first and, oh my! so far last true pan-Slavists" 50 ; finally, in 1829, he developed an enthusiasm for the adventurous theses of the RuthenianUkrainian philologist Yuriy I. Venelin (1802-1839), who, in a history of BulgarianRussian relations financed by Pogodin, interpreted not only Bulgarian history, but also that of the Avars, Khazars, Huns, Scythians and Sarmatians as Slavic, and thus counted the Slavs among the oldest tribes in Europe ${ }^{51}$. From the 1830s, Pogodin also introduced aspects of Slavic history into his lectures on Russian history ${ }^{52}$. In doing so, he defined the language, literature, ethnography and civic rights of the Slavic peoples as independent fields of investigation, thereby paving the way for Russian academic studies of the Slavs, which he also hoped to promote with his 1840 Russian translation of Ján Kollár's programmatic work On Literary Reciprocity ${ }^{53}$. At the same time, he also sought to popularize knowledge about the Slavs in the wider public domain through his own journals, the Moskovskij Vestnik (1827-1830) and the Moskvitjanin (1841-1856), the latter being used not least by the Slavophiles.

Pogodin's interest in Slavic studies gained a particular impulse from his travels abroad, which led him to Central and Western Europe for a total of seven times between 1835 and $1867^{54}$. On these travels, he made personal contact with leading

jazyka slavjanskogo po drevnemu narečiju, na koim rossijane, serby i drugie slavjane grečeskago izpovedanija i dalmaty-glagolity rimskago izpovedanija imejut cerkovnyja knigi, vol. 1, S.-Peterburg 1833; vol. 2-3, S.-Peterburg 1834; see also U. Picht, Pogodin (as in footnite 35), pp. 25, 34.

50 M.P. Pogodin, Nečto o svjatych izobretateljach slavjanskoj hramoty, Kirille i Mefodii, Severnyj Archiv 1826, 4, pp. 348-357; idem, Reč́, proiznesennaja v zasedanii moskovskago obščestva ljubitelej rossijskoj slovesnosto predsedatelem, 11 maja 1863 goda, v pamjat' o sv. Kirille i Mefodie, [in:] Kirillo-Mefodievskij Sbornik v pamjat's o soveršivsemcja tysjaščeletii slavjanstkoj pismennosti i christianstva v Rossii, ed. M.P. Pogodin, Moskva 1863, pp. 81-144 (emphasising the impact the apostles' heritage in form of the church-slavonic literacy on Slavic unity); idem, Reč', proiznesennaja v sobranii slavjanskogo blagotvoritel'nogo komiteta, 1869 goda, fevralja 11 dnja, [in:] Michail P. Pogodin, Izbrannye trudy (as in footnote 40), pp. 460-464, the quotation p. 463.

51 J.I. Venelin, Drevnie i nynešnie Bolgare v političeskom, narodnom, istoričeskom i religioznom ich otnošenii k Rossijanem, vol. 1, Moskva 1929; vol. 2, Moskva 1841.

52 F.A. Petrov, M.P. Pogodin i sozdanie kafedry rossijskoj istorii v Moskovskom universitete, Moskva 1995, pp. 73-77.

53 Published in Otečestvennaja Zapiski 1840.

54 Besides the 'political letters' discussed below see M.P. Pogodin, Godv čužich krajach (1839). Dorožnyj dnevnik, Moskva 1844; on the 1839 journey also D. Offord, Journeys to a Graveyrad. Perceptions of Europe in Classical Russian Travel Writing, Dordrecht 2005, pp. 119-141. 
West and South Slav representatives of the pan-Slavic idea, with some of whom he subsequently enjoyed a lifelong friendship ${ }^{55}$. As a passionate collector, he used these direct contacts to acquire Slavic manuscripts, books, and other materials for his study library, at the same time creating an important primary source for the emergent Russian Slavic Studies ${ }^{56}$. He also used his personal connections to initiate publications on Slavic issues and editions of Slavic written documents, but also to provide material assistance to West and South Slavic friends in the form of money and books, for whom he cleverly activated his excellent contacts with the Russian government and court circles, as well as with the intellectual circles of Moscow and Petersburg society.

Pogodin's early interest in Slavic issues was still largely motivated by and based on scholarly concerns. But, after his first journey abroad and direct encounter with West Slav activists of the pan-Slavic movement, his image of the Slavs began from the mid-1830s to take on a clear political character. And, in the 1840-50s, the (foreign) political charge of his pan-Slavic ideas then gained additional momentum as a result of two circumstances. On the one hand, the withdrawal from his professorial post in Moscow (which was ultimately involuntary) ${ }^{57}$ caused the scholar to turn even more to journalism and to focus more on day-to-day political issues. On the other, the worsening of foreign political conflicts (revolutions, the Crimean War) motivated the historian who was interested in everyday political events to employ his image of history ever more aggressively in the defence of Russian interests. This resulted in the specific juxtaposition of Russian nationalism and pan-Slavic thought that characterized Pogodin's pan-Slavism during the remainder of his life. Pogodin

55 The related correspondence in M.P. Pogodin, Pis'ma k M. P. Pogodinu iz slavjanskich zemel' (1835-1861). Vypusk I: Pis'ma O.M. Bodjanskago, Moskva 1879; Vypusk II: Pis'ma P.I. Šafarika, Moskva 1880; Vypusk III (I poslednij), ed. D.Č. Nil Popov, Moskva 1880; for another edition of Pogodin's correspondence with Pavel Josef Šafarik containing some more letters of Pogodin himself see Korespondence Pavla Josefa Šafarika s ruskými učenci (1825-1861). Bd. 2, ed. V.A. Francev, Praha 1928, pp. 485-812; cf. also E.V. Širokova, P.J. Šafarik i M.P. Pogodin. K voprosu česko-russkich naučnych svjazach 30-60ch gg. XIX v., Moskva 1999; E. Kucharska, Michała Pogodina zainteresowania polskie, Warszawa-Wrocław 1978.

\section{Katalog biblioteki M. P. Pogodina, ed. I. Kovrigina et al., Moskva 1993.}

57 Pogodin stepped down from his professorial chair in 1844 due to conflicts with colleagues hoping that he would be re-called onto the chair and thus being strengthened in his position; this, however, turned out a miscalculation since Count Stroganov, the curator responsible for the universities, used the opportunity to place the historian Sergej M. Solovev (1820-1879) on the chair instead of Pogodin; cf. K.-D. Grothusen, Die Historische Rechtsschule (as in footnote 42), p. 36. 
gave particularly strong expression to this pan-Slavism in his "political letters”, which initially he distributed in handwritten form, and then only later published ${ }^{58}$.

In a first letter that he wrote in 1838 , he appealed directly to the crown prince, the then twenty-year-old Alexander Nikolaevič $(1818-1881)^{59}$. Unlike the West and South Slavic preachers of the Slavic idea, Pogodin was not content to address only powerless intellectuals; instead, he wanted to convince no less a person of his ideas than the "heir to a powerful empire" ${ }^{0}$. However, the letter never reached the heir to the throne, since count Sergej G. Stroganov (1794-1882) did not forward it, but returned it later to Pogodin - with the marginal note: „Many words, only one new thought (pan-Slavism), and that, too, is wrong" ${ }^{\prime 1}$. This pan-Slavic thought was based on the sheer size of Russia, which, according to Pogodin, would be even greater if to its sum of 60 million inhabitants were added „another 30 million of our brothers and cousins, the Slavs that are sown all over Europe”, „the Slavs, in whose veins the same blood flows as in ours, who speak the same language, and are thus, according to natural laws, of one purpose with us - the Slavs, who, despite their geographical and political separation, form with us, according to origin and language, one spiritual whole”, and who together make up the "nin[th] part of the entire humankind” ${ }^{2}$. This sheer quantity alone convinced Pogodin that "such a great people, a people of such multitude, spread so widely, of such capabilities and talents, with such a language" would undoubtedly make its contribution to the general history of humankind, and that, „in any case, the future belongs to the Slavs”. For Pogodin it was obvious that Russia was the Slavic tribe that will, „in terms of size and language and the unique breadth of what it comprises, represent the whole world of Slavic peoples", guaran

58 M.P. Pogodin, Politische Briefe aus Rußland. Aus der russischen Handschrift übersetzt, Leipzig 1860; idem, Istoriko-političeskie pis'ma i zapiski v prodolženii krymskoj vojny 1854-1856, Moskva 1874.

59 M.P. Pogodin, Politische Briefe (as in footnote 58), pp. 1-19; Russian version: Pis'mo k Gosudarju Cesarevič, Velikomu Knjazju, Aleksandru Nikolaeviču (nyne carstvujuščemu Gosudarju Imperatoru) v 1938 godu, [in:] Michail P. Pogodin, Izbrannye trudy (as in footnote 40), pp. 178-187.

60 This quote from H. Kohn, Die Slawen und der Westen. Die Geschichte des Panslawismus, WienMünchen 1956, p. 130.

61 Quoted after ibidem, p. 132.

62 This and the following quoations in M.P. Pogodin, Politische Briefe (as in footnote 58), pp. 2-3; in a later letter (ibidem p. 108) Pogodin stresses that the 30 million non-Rusian Slavs are „of one tribe with Russia, tied to Russia by the closest bonds of blood, language and religion”; this thought also already in M.P. Pogodin, Vzglad na russkuju istoriju. Lekcija pri otkrytii kursa v sentjabrje 1832 g., [in:] K.B. Umbraško, M. P. Pogodin (as in footnote 40), pp. 239-249, the quotation p. 240. 
tee, „in its present state as in its past, future greatness”, and is in a position „to crown and complete the development of humanity" ${ }^{63}$.

That this was precisely the view shared by the Slav brothers suppressed by the Austrians was something that he tried to persuade his patron, Uvarov, the minister of public education, of in a letter from early $1840^{64}$. Despite „consistent and systematic persecution", Pogodin wrote, the courage of the Habsburg Slavs remains unbroken, but they incline towards Russia „as a united body [...] and with heart and head”. Russia they „behold, like the magi beheld the star from the East. Their hearts beat for Russia, their thoughts and wishes are directed to Russia, there in the East reside their hopes. They feel that there lies salvation". Only the recalcitrant Poles are dancing out of line, and „do not grasp the fortune and the honour of being united with Russia”. All other Slavs, on the other hand, are hoping for "the great Slavic empire, [with] Russia at its head, from the Pacific Ocean to the Adriatic Sea, an empire like no other in history, one that will command the rest of the world". Pogodin knew of course that such aggressive pan-Slavic thoughts were not shared by tsarist politics, and, in order nevertheless to persuade his addressee of the correctness of these ideas, he appealed to "sacred duty, Christian duty”. This duty dictates that Russia, as the only Slavic tribe not „subjugated, oppressed, miserable” ${ }^{\prime \prime}$, provide „help to its brothers", and even act as "protector and head of the whole family”. Since for Pogodin the language represents the central bond unifying all Slavs, he attached to this image the linguo-political vision that the lost linguistic unity of the Slavs will be restored by Russia. The Russian language is „so powerful and unites so completely all the advantages that the other Slavic languages have individually that it can be regarded as their natural representative”. It will therefore also become, „on its own accord, without coercive measures, sooner or later, the general Slavic literary language" 66 .

\footnotetext{
63 M.P. Pogodin, Politische Briefe (as in footnote 58), pp. 17-18.

64 Ibidem, pp. 19-60; Russian version: Pis'mo k ministru narodnogo prosveščenija po vozvraščenii iz putešestvija po Evrope v 1839 godu, [in:] Michail P. Pogodin, Izbrannye trudy (as in footnote 40), pp. 188-210.

65 Already in his inaugural lecture at Moscow University Pogodin in 1834 explained, how the early Slavic history which originally developed simultaneously during the later course of history grew apart due to various circumstances and how the Slavic tribes fell into isolation and ultimately all - except of one, sc. the Russian, lost their independence; M.P. Pogodin, O vseobščej istorii. Lekcja pri vystuplenii v dolžnost' ordinarnago professora $v$ Imperatorskom Moskovskom universitete, [in:] idem, Istoričeskie aforizmy (as in footnote 43), pp. 113-128, esp. pp. 118-119.
}

66 The quotations in M.P. Pogodin, Politische Briefe (as in footnote 58), pp. 22, 29, 32, 34, 38, 39. 
That such an interpretation of the Slavic idea (an interpretation legitimizing Russian supremacy) did not, despite the tsarist government's official reticence, wholly miss the mark in 1840 was demonstrated by the fact that, on reading the letter, Nikolay I sent Pogodin, together with a donation of 2000 rubles meant for Jozef Šafarik and Václav Hanka (1791-1861), a sign of his goodwill ${ }^{67}$. But greater official resonance was not forthcoming; a second report also addressed to the minister of public education in 1842, in which Pogodin further extended the idea of an entire Slavic state extending from the Pacific to the Adriatic, met more with criticism than praise ${ }^{68}$. Again, Uvarov avoided giving Pogodin's letter to the tsar. Soon afterwards (1847), he generally forbade any expressions of sympathy for foreign Slavs. In order not to jeopardize its relations with neo-absolutist Austria, the tsarist government pronounced a strict ban on any support for Slavic movements ${ }^{69}$.

It was only when the official Russian-Austrian friendship cooled noticeably in the Crimean War, and the Habsburg Empire was then increasingly perceived as an opponent of Russian interests, that Pogodin's prospects rose of finding for his panSlavic ideas a more open ear among government members and in society as a whole. At the beginning of December 1853, scarcely two months after the Turkish declaration of war on Russia, Pogodin wrote a letter to countess Antonina D. Bludova (1813-1891) that found great resonance. This time, the letter also reached the tsar, who commented on it in detail ${ }^{70}$. In the letter, Pogodin asked rhetorically, which Eu-

67 O.V. Pavlenko, Rußland und die Donauslaven (1848 bis 1871), [in:] Der Austroslawismus (as in footnote 11), pp. 156-177, here p. 164.

68 M.P. Pogodin, Politische Briefe (as in footnote 58), pp. 60-91; Russian version: Vtoroe donesenie ministru narodnogo prosveščenija o putešestvii 1842 goda, preimuščestvenno v otnošenii k slavjanam, [in:] Michail P. Pogodin, Izbrannye trudy (as in footnote 40), pp. 211-228. When these two letters in 1859 were published for the first time in Russia in Russkaja Beseda the editors of this journal called Pogodin's vision a „luckily unrealizable dream”; intheir opinion such a sately union would only give each of the [Slavic] tribes intellectual independence” and they added: „No” The banner of Russia should not be, in our view, Pan-Slavism in a political sense, not centraliztion, but the recognition of the rights of each nation to lead a self-determined life, to have an own existence." They made it, however, at the same time perfectly clear that a free union of independent Slav tribes” could only exist „unter the protection and shield of Russia"; Russkaja Beseda 4 (1859), 'Smies' pp. 53-88, the quotation p. 61.

69 O.V. Pavlenko, Rußland und die Donauslaven (as in footnote 67), pp. 165-166; U. Picht, Pogodin (as in footnote 35), p. 70.

70 M.P. Pogodin, Politische Briefe (as in footnote 58), pp. 92-104; Russian version: K grafine B... oj, o načavšejsja vojne (1853 goda, dekabrja 7), [in:] Michail P. Pogodin, Izbrannye trudy (as in footnote 40), pp. 265-273 (here the underlinings and the handwriting marginal notes of Czar Nikolay I are especially indicated). 
ropean allies Russia could now count on in the situation of war. Even if tsar Nikolay dismissed this question and commented in a marginal note, „No one, and we do not need anyone, either" ${ }^{\prime 1}$, Pogodin was convinced that only "the Slavs, according to blood and language, according to spirit and history and faith” are „our brothers”, „our only, our reliable, our mighty allies”. Russia should therefore take advantage of the favourable situation. Otherwise, „if we sacrifice Slavic interests, if we disappoint the budding hope of the Slavs, or place their fate into the hands of other powers", Pogodin continued, then what would threaten the tsarist empire will be „not merely one disorderly Poland", but ten similarly embittered opponents ${ }^{72}$.

The success of this letter encouraged Pogodin to write a whole series of similar political letters; 14 others followed in 1854 alone. In one, he modified the idea of an entire Slavic state, arguing instead that it should be a Slavic federation, a „Danube confederation". Its capital would have to be located in Constantinople, and of course its leadership assumed by Russia - „not because of Russia's desire for it, not from ambition or from its hunger for new countries, but from the nature of things, just as the Russian language has to become over time the general literary language for all Slavic tribes, not by order of the Russian government [...], but according to philological laws". All the individual countries united in this confederation should „govern themselves [...], without interference from the rest, including from the [Russian] protective power, and only turn when it comes to general matters to the Bundestag in Constantinople and to the Russian emperor, as head of the confederation and father of the most numerous Slavic tribe (that is to say, the Russian)" "73. This confederation must also, as he explained in a further letter, include Poland, which, from a Russian perspective, is "certainly not a country in itself”, but merely „an accessory border country”. Its restoration could therefore come about at best „within the borders of the Polish language". However, in view of the open hostility shown to them by Prussia and Austria, the Poles could only hope for a partial restoration of their state from the „magnanimity” of the tsar and of the "Slavic tribes bound to Russia." ${ }^{4}$ What the

\footnotetext{
71 Ibidem, p. 271.

72 M.P. Pogodin, Politische Briefe (as in footnote 58), pp. 101, 103.

73 Ibidem, pp. 136-162, the quotations pp. 153-155; Russian version: Opasnosti Rossii. O diversijach i sojuznikach. Značenie vojny. Sostajanie narodnogo ducha (Maja 27, 1854), [in:] Michail P. Pogodin, Izbrannye trudy (as in footnote 40), pp. 274-288.

74 M.P. Pogodin, Politische Briefe (as in footnote 58), pp. 162-180, the quotations pp. 162, 166, 170.
} 
Poles thought of such a prospect was expressed in January 1863 in another uprising; Pogodin could only condemn this dramatic attempt at liberation ${ }^{75}$.

When with Alexander II a changed political atmosphere set in, the Slavic question in the late 1850-1860s gained considerably more weight in Russia. The panSlavic ideas propagated by Pogodin now not only attracted increased attention, but also found an institutional basis in a Slavic charity committee founded under the patronage of the crown prince in 1857/58. The committee, headed by Pogodin from March 1861, now openly raised funds to promote education and literature among the South Slavs as well as Slav students at Russian universities, but above all to support the Orthodox Church in the Balkans ${ }^{76}$. Pogodin's pan-Slavism then experienced a further institutional highlight in May 1867, when an ethnographic exhibition organized by the Moscow Society of Friends of Natural History, Anthropology and Ethnography offered the opportunity to organize under Russian auspices a second general congress of Slavs (the first had been held in Prague in 1848) ${ }^{77}$. A total of 84 Serbs, Czechs, Croats, Ruthenians, Slovaks, Slovenes, Montenegrins, Sorbs and Bulgarians - but no Poles - participated in this „second Slav congress”. Not a few of the guests from the Habsburg Empire, as for example the Slovenian pastor and linguist Matija Majar-Ziljski (1809-1892), hoped that their participation and cooperation with Russia would give them new impetus for their national cause, especially since the newly agreed Austro-Hungarian settlement had set the Habsburg Slavs back once again.

75 Cf. M.P. Pogodin, Pol'skij vopros [1867], [in:] Michail P. Pogodin, Izbrannye trudy (as in footnote 40), pp. 346-350; idem, Polskoe delo (pisano v 1865 godu), [in:] ibidem pp. 360-395; on Pogodin's position as to the 'Polish question' see also E. Kucharska, Michała Pogodina zainteresowania (as in footnote 55), pp. 63-74.

76 S.A. Nikitin, Slavjanskie komitety v Rossii v 1858-1876 godach, Moskva 1960; U. Picht, Pogodin (as in footnote 35), pp. 180-186; Z. Zlatar, "For the Sake of Slavdom" II. M. P. Pogodin and the Moscow Slavic Benevolent Committee: A Collective Portrait of 1870, East European Quarterly 40 (2006), 3, pp. 255-291. Pogodin repeatedly explained the objectives of the committee, which in the late 1860s, early 1870s established branches in Peterburg, Kiev and Odessa, in speeches; M.P. Pogodin, $V$ predvaritel'nom sobrainii Kievskogo otdelenija Slavjanskogo komiteta, 1-go oktjabrja, 1869 goda, [in:] Michail P. Pogodin, Izbrannye trudy (as in footnote 40), pp. 455-459; idem, Reč', proiznesennaja v sobranii slavjanskogo blagotvoritel'nogo komiteta 1869 goda, fevralja 11 dnja, [in:] ibidem pp. 460-464; idem, Reč', proiznesennaja predsedatelem slavjanskogo komiteta, u sebja $v$ dome, za obyčnym obedom v vozpominanie o pervom Slavjanskom s-ezde, 16 Maja, 1871 goda, [in:] ibidem pp. 482-485.

77 Vserossijskaja ètnografičeskaja vystavka i Slavjanskij s-ezd v maje 1867 goda, Moskva 1867; H. Kohn, Die Slawen (as in footnote 60), pp. 144-160; M. Tanty, Panslawizm, carat, Polacy. Zjazd Stowiański w Moskwie 1867 roku, Warszawa 1970; U. Picht, Pogodin (as in footnote 35), pp. 186-202. 
Pogodin, on the other hand, took advantage of the congress to appeal in not one, but several speeches to the pan-Slavic consciousness of the participants, and to show them the great importance of their being connected to Russia. Soon after their arrival in Moscow, he called in greeting to them: here „in Moscow lies the germ, the core, the cradle of the Russian state; Russia was born out of Moscow, in Moscow the idea of Slavic unity was born and given strength, in Moscow burned the sacred sympathy for the fate of the suffering tribes". In the whole tsarist empire there prevails "one and the same thought, one and the same feeling, [...] that everywhere and among everyone love for the Slavs is increasing"78. In actual fact, according to Pogodin in a dinner speech that he gave five days later, „all Slaves are kissing each other in a friendly manner and heartily embracing one another", with only the Poles unfortunately choosing to „stand apart”. But hopefully they, too, will still recognize their blindness, put aside their hostility, and trust in the good nature of the tsar. Then, according to Pogodin, „our Russian and Slavic joy will be complete" ${ }^{\text {. As }}$ a farewell, he assured the guests at the end how their destiny was a matter that was very close to the Russian hosts, and how much their hosts were convinced that, "of all the European peoples, the Slavs were the natural, closest friends of the Russians”. But the guests should also recognize that they „can hope in Europe for no one else but the Russians”. They should therefore „leave behind all old prejudices about the Russian greed for power, and allegedly evil intentions”, and trust that Russia „needs nothing, no countries, no people. [...] We want nothing from you but your love. Only this, what we also give to you, we ask of you" ${ }^{\prime 0}$.

Such appeasing words could ultimately not deceive the West and South Slav guests about the true interests of their hosts. Even Pogodin himself, although his speeches visibly sought restraint, certainly offered occasion for the guests to have their doubts. He announced, for example, his conviction that the congress had shown that „all Slavic tribes desperately need for their intercourse one language with one alphabet" ${ }^{11}$. With this, he had nothing in mind but his old idea of raising Rus-

78 M.P. Pogodin, Za pervym obščim užinom po priezde Slavjanskich gostej v Moskvu, Maja 16, 1867 goda, [in:] Michail P. Pogodin, Izbrannye trudy (as in footnote 40), p. 438.

79 M.P. Pogodin, Reč' na obede v čest' Slavjan, Maja 21, v Sokol'nikach, [in:] Michail P. Pogodin, Izbrannye trudy (as in footnote 40), pp. 439-440.

80 M.P. Pogodin, Na rasstavanii co Slavjanskimi gostjami, 1867 goda, Maja 27 dnja, [in:] Michail P. Pogodin, Izbrannye trudy (as in footnote 40), pp. 441-442.

81 Ibidem p. 441. 
sian to the general Slavic literary language. Other representatives of the host country were clearer in defining the acceptance by all Slavs of the Russian language, as well of Orthodoxy, as the indispensable prerequisite for the celebrated Slavic unity ${ }^{82}$. Under such circumstances, the fact that the „Slav congress” remained unsuccessful, and was not, as Pogodin had hoped, repeated regularly thereafter, was therefore hardly surprising. But not only the guests lavishly entertained in Petersburg and Moscow disappointed the Russian pan-Slavists in the end. The tsarist government also made only temporary and half-hearted use of the legitimating potential of the all-Slavic idea. At the latest, when it returned to the Ottomans half of the Bulgarian territory conquered in the Russian-Turkish war of 1878, did it once again parade the pan-Slavic idea to its followers. Pogodin, who had died three years before the war, himself acknowledged at the end of his life that his pan-Slavic hope that Russia would free its Slavic brothers from the yoke of Austrian and Turkish foreign rule had not come to fruition, and that his idea of an entire Slavic state, a „Danube confederation", belonged ultimately to the realm of fantasy.

It is true that Pogodin did not admit that this fantasy served primarily as an opportunity to legitimize and propagate a tsarist-Russian pre-eminence in Central and South-Eastern Europe, even if the tsarist government hardly ever took up this opportunity. Joachim Lelewel also never explicitly understood his messianic concept of a democratic federation of all Slavs as an instrument to legitimize and propagate the restoration of a Polish republican statehood. Nevertheless, the historiographical constructions, the imagining of Slavic community and reciprocity, which the Polish and the Russian historians developed under very different conditions and from very different motivations, were not only a typical product of contemporary East (Central) European, romantic thought; they were also two outstanding examples of the numerous attempts to use the romantic concept of Slavic unity for major political ends.

82 M. Tanty, Panslawizm (as in footnote 77), pp. 107-117. 
Nadesłany: 17 VII 2018

Nadesłany po poprawkach recenzyjnych: 19 XI 2018

Zaakceptowany: 20 XI 2018

prof. dr Eduard Mühle

Historisches Seminar

Abteilung für Osteuropäische Geschichte

Westfälische Wilhlems-Universität Münster

Domplatz 20-22

48143 Münster

muehleed@uni-muenster.de

\section{Inventing Slavic Unity or the Political Use of a Romantic Concept. The Case of Mikhail P. Pogodin and Joachim Lelewel}

The Idea of a Slavic community constituted by a common language, early history, and culture since the early $19^{\text {th }}$ century was developed into an instrument of concrete national-political demands and constitutional plans. A common course of political action in the spirit of general Slavic solidarity and commonality, however, was hindered by the particular egoisms of individual Slavic nations. Especially Poles and Russians took a specific stance in handling the Slavic idea. The article explores this distinct Russian and Polish approach by looking at the pan-Slavic concepts of two outstanding Polish and Russian historians - Joachim Lelewel and Michail P. Pogodin. 